\title{
From contention to mainstream: valuing and institutionalizing moral products
}

\author{
Nadine Arnold \\ IDHES, ENS Cachan, France \\ Department of Sociology, University of Lucerne, Switzerland
}

\author{
Birthe Soppe \\ Centre for Entrepreneurship, University of Oslo, Norway
}

Forthcoming in Krücken, Georg; Mazza, Carmelo; Meyer, Renate E. and Walgenbach, Peter: New Themes in Institutional Analysis. Topics and Issues from European Research, Edward Elgar Publishing Limited.

The authors are listed alphabetically. The authors would like to thank two reviewers as well as all participants at the New Institutionalism Workshop 2014 in Rome, EGOS 2014 in Rotterdam, and the Brownbag Seminar at ESSEC Business School in Paris for their helpful comments on earlier versions of this chapter. This research was conducted while Birthe Soppe was at Stanford University, SCANCOR, and Nadine Arnold at ENS Cachan, IDHES, where they received thoughtful comments and suggestions.

\begin{abstract}
The study aims at thoroughly understanding the creation and institutionalization of what are called "moral markets'. We examine the development of mundane commodities into morally value-laden products, which are culturally supported and demanded in the domain of mass markets. By analyzing a rich set of archival data on the history of fair trade in Switzerland over three decades, we trace the early beginnings, development, and mainstreaming of products that are imported from developing countries and sold at a price premium to guarantee the producers a decent remuneration. In our analysis, we show that the institutionalization of fair trade is the outcome of a valuation process, which is characterized by changes in product-level valuation practices and also by an increase in the blending of moral and economic values. Our contribution provides important implications with regard to the role of values and valuation in institutionalization processes.
\end{abstract}

\section{INTRODUCTION}

The emergence of moral markets - markets for products that are bought mainly because of their admirable social and ethical values - is a ubiquitous phenomenon in the contemporary Western economy. Prominent examples of product categories that explicitly evoke moral values include ethical fashion, animal-friendly and cruelty-free cosmetics, organic food, locally manufactured toys, open source 
software, green electricity, and sustainable tourism. ${ }^{1}$ These products do more than fulfill functional needs. First and foremost they are valued for their varied moral qualities, including social justice, environmental preservation, freedom, health, and care for children and animals. Our study is motivated by a desire to more fully understand the creation and institutionalization of moral markets.

Product market categories are formed and institutionalized when producers, consumers, and a broader variety of audiences arrive at a shared understanding about the meaning of products. Formation of a new category also involves agreeing upon a label that is well understood and unambiguously linked to the products (Rosa et al., 1999; Zuckerman, 1999). Product market categories are socio-cognitive constructs whose meaning extends beyond functional or utilitarian purposes; in the case of moral products, the products become inherently imbued with social and ethical values.

Given the proliferation of moral products as well-accepted and institutionalized elements of contemporary markets, we ask the following: how do mundane commodities develop into morally valueladen products that are culturally supported, taken for granted, and demanded in the domain of the mass market? How do moral and social values become integrated into products? First, in the literature on categories, most attention has focused on the effects of categorization, such as enabling coordination among producers and consumers (Rosa et al., 1999), generating comparability (Porac et al., 1999), and commensurability (Espeland and Stevens, 1998). As a result, we know much less about processes of category emergence and development (Glynn and Navis, 2013; Khaire and Wadhwani, 2010). Second, the process by which values become attached to objects and ideas has only been minimally examined in institutional theory. This is surprising given that values are a core concern in institutional theory. Institutional scholars have highlighted the important role that values, in particular moral values, play in underpinning legitimacy (Suchman, 1995), making institutions and organizations meaningful (Gehman et al., 2013; Suddaby et al., 2010), affecting change processes (Vaccaro and Palazzo, 2015), and guiding decision-making (Sheperd et al., 2013). Institutions are based on values, and as such, values are central to what makes institutions so influential and meaningful to business and society. Consequently, more work is needed to advance our knowledge of how values permeate institutions - or what Stinchcombe referred to as 'the guts of institutions' (Stinchcombe, 1997, p. 17). We seek to contribute to this research agenda by drawing on recent developments in economic sociology on valuation and institutional theory. We examine a historical process of valuation that culminated in the institutionalization and mainstreaming of a product category infused with moral values. By mainstreaming, we mean that products become part of the dominant social order; they diffuse into the domain of the conventional mass market.

In his early work, Selznick (1957) defined institutionalization as a process of infusing value. Because Selznick's 'treatment of institutionalization informs us that values are instilled; not how this occurs' (Scott, 1987, p. 495, original emphasis), we direct our attention to recent developments on valuation in economic sociology. In economic sociology, values and valuation have developed into vibrant topics. Works by Viviana Zelizer in particular have highlighted how moral values can become ascribed to economic objects and how closely entangled moral values are with socio-economic outcomes, such as the demand for products and the creation of market categories. In her study of the market for life insurance in the United States, Zelizer (1979) showed that this market only emerged and became valuable to consumers once it became tightly linked to values of caring for one's family after death. Recently, Waarden and Van Dalen (2013) have shown that religious norms play an important role in transforming 
the meaning of existing products into Muslim-safe halal products, which can be sold at a higher price. Thus, the moral value of products is closely entangled with economic value and is not directly observable, as 'value seems detached from the materiality and in very obvious ways socially constructed' (Aspers and Beckert, 2011, p. 30).

Both institutional theory and the valuation literature share overlapping interests: both are concerned with processes of social construction, and both are concerned with the creation of meaning and value. Institutional theory, on the one hand, typically emphasizes the power of meaning and taken-forgrantedness, but is less well equipped to explain how valuing occurs or is altered. The literature on valuation, on the other hand, provides useful insights into how value is constructed and ascribed to objects and how the dynamics of meaning-making occur. However, work on valuation in economic sociology has primarily focused on economic valuation in market settings, while institutional theory is mostly concerned with social values and cultural influences. We attempt to cross-fertilize the literature on valuation with institutional theory, as it might be fruitful in shedding light on how ideas or objects become charged with new assemblages of values as well as how the dynamics of valuation occur.

The empirical setting of our study is the emerging market for fair trade products in Switzerland. Fair trade refers to a market for products whose value lies more in their moral qualities than in the utility of the goods themselves. Drawing on an in-depth, historical case study of the birth and institutionalization of fair trade in Switzerland over almost three decades (1970-97), we trace the early beginnings, development, and mainstreaming of products that are imported from developing countries and sold at a price premium to guarantee Southern producers a decent remuneration. This is a product market category that is deeply imbued with moral values and has become well established under the label 'fair trade'. Our analysis shows that the mainstreaming and institutionalization of fair trade was not purposefully planned at the outset but is rather the outcome of a historical valuation process. Our study illuminates that the idea of fair trade has proceeded through three stages, which we label invention, niche, and mainstream. Each stage is characterized by distinct valuation activities and a distinct conceptualization of the products. Initially, the products were utilized by movement activists as 'symbols' of morality, marked by a symbolic price that was used to establish solidarity between Southern producers and Northern consumers and to protest the dominant political and economic order. Then, these pioneering advocates codified their moral principles into permanent selling and trading practices and framed fair trade as an 'alternative' to conventional economic practice. High levels of contestation marked both the invention and niche phases: external constituents challenged the new moral valuation principles and internal constituents - the movement activists themselves - struggled between ethical and commercial values. In the 1990s, fair trade entered the conventional market place as 'a plus for all'- moral and economic values became tightly integrated, and a standardization organization and label were formed that now 'certify' the moral qualities of the products. In analyzing the course of this process, we find that the 'value architects' of the fair trade movement provoked new valuation criteria and engaged in a range of valuation practices that changed the social and economic worth of the products in a long-lasting way. We suggest that, after almost two decades of contestation by both internal and external constituencies, the institutionalization of fair trade and its diffusion into the mainstream market place occurred due to changes in product-level valuation practices and a blending of moral and economic values. 
This chapter's findings demonstrate how fair trade emerged and how it could grow out of its niche and settle into the domain of the mainstream market place as a highly credible product category imbued with moral values. We introduce the concept of "value architects'2 and show how the value architects of fair trade contributed to these socio-economic transformations by engaging in a range of practices that highlighted certain moral qualities and attributed them to products. Such developments, we assert, can only be reconstructed from a historical perspective. Illuminating how value is socially constructed and pointing out the importance of valuation dynamics in processes of institutionalization and socio-economic shifts, our chapter has important implications for the role of values and valuation in institutional theory.

The roadmap of this chapter is as follows. We will briefly present our theoretical orientation, focusing on the literature on valuation. We then describe our empirical setting and methodological approach, which mainly consists of a detailed historical case study based on a rich archival dataset. Our empirical case is then presented, and we conclude with a discussion of our key findings and contributions.

\section{LITERATURE ON VALUATION}

\section{Value and Valuation}

What exactly is the value of a product and where does this value come from? Value is an ambiguous term. Traditionally, economists study value as the economic (monetary) value of a good, while sociologists focus on (social) values. Scholars of economic sociology have begun to transgress this once classical divide (also known as Parsons' Pact; see Stark, 2009) by acknowledging the interrelation of value and values and the social underpinnings of economic value. To be sure, economic value and social values are closely entangled. To provide some extreme examples of this entanglement, money can take on social meaning (Zelizer, 1989), while intangible things such as nature, love and fairness can come to be assigned a monetary value (Fourcade, 2011). Stark (2009) uses the notion of 'worth' to avoid confusion around these terms and to emphasize how central moral values are to economic value. ${ }^{3}$

In the economic sociology literature on valuation, a critical distinction is being made between value and valuation. Value can be understood as a noun or as a verb (Dewey, 1939). While the former refers to objects as having value (static conception), the latter sheds light on the processes through which value is constructed and attributed to an object. This value-as-a-verb perspective has given rise to studies of valuation. Work in this realm approaches value as something that is not pre-existing but rather as something that is created.

Dynamic processes of valuation have attracted increasing attention from economic sociologists (Antal et al., 2015; Beckert and Aspers, 2011; Fourcade, 2011; Lamont, 2012), suggesting that valuation is rooted in social practice. The shift from the notion of value (as a noun and as property) to valuation (as a process and practical action) is what Muniesa (2011) calls a pragmatist approach to valuation.

Following this pragmatist idea, valuation refers to the process by which goods acquire value. As such, practices can either infuse meaning and value (valuation), or alter the value of products (revaluation).

Although the literature in economic sociology is predominantly concerned with understanding the social underpinnings of economic value and monetary valuation (i.e., pricing), it can be used as a fruitful vintage point for our purposes. As our core interest is in how moral principles become fabricated into products, we give primacy to social value over economic value (without dismissing economic value). 
For example, we do not explicitly focus on how the price of moral goods is constructed. This has been done elsewhere (e.g., Reinecke and Ansari, 2015). Rather, we seek to extend the insights derived from the literature on economic valuation to processes of social valuation to better understand how the (social and economic) worth of products can be shaped and changed. Hence, we do acknowledge that moral qualities can contribute to the economic value of products, but we also argue that pricing may be only one out of a range of valuation practices that can provoke and signal moral qualities.

\section{Valuation as Practice}

We adopt the pragmatist perspective that valuation is rooted in action and not determined a priori based on the (material) value of an object itself (Muniesa, 2011). Rather, the worth of products is shaped and actively constructed. Reviewing the literature, we present three areas of social practice that have been highlighted in valuation studies: utilizing market devices, discourse, and operations around products. These practices have been credited with the ability to render the value of products visible, link new valuation principles to products, and help consumers to identify and categorize products.

Market devices are socio-technical instruments aimed at helping to identify and judge the qualities of products. They are essential in the construction and coordination of markets (Callon et al., 2007). Market devices cover a wide range of tools, including logos, labels, standards, booklets, designs, advertisements, pricing, and packaging. They are typically designed by market actors, such as producers, to render the value of products explicit and perform calculative functions. Most work has focused on the role of market devices in contributing to economic valuation. Recently, however, scholars have shifted their focus and demonstrated how market devices are utilized to elicit not only economic but also social values. For example, Yenkey (2011) shows how advertising campaigns that evoke desirable, aspirational social values have been used by state agencies in Kenya to legitimate a newly founded stock exchange (and not to determine the price of the initial public offerings). Dubuisson-Quellier (2013) finds that social movements rely on market devices such as booklets and shopping guides to highlight the ethical aspects of products and trigger new principles of worth related to local sourcing, reduced packaging, and environmental impact. Similarly, there are examples of how the practice of pricing can emphasize specific qualities of products. For instance, extreme markets such as luxury goods demonstrate how consumers attribute higher social values to a product when it has a higher price (Aspers and Beckert, 2011). In this sense, market devices, including pricing, make goods not only calculable, but may act as signals of superior qualities and may therefore be important tools that can imbue products with new valuation principles.

Studies that focus on discourse have particularly highlighted the role of frames. Frames have been shown to be crucial to socio-economic processes and outcomes, such as the attribution of value to products and the legitimization of new product categories. They help to reduce socio-cultural complexities and 'render events or occurrences meaningful' (Benford and Snow, 2000, p. 614). Djelic and Ainamo (1999) provide an example of how Frederick Worth, a pioneer of women's haute couture in France, framed his fashion as an 'aristocratic way of life', thus invoking a lifestyle to which many of the upper class in nineteenth-century France aspired. Weber et al. (2008) show how grass-fed beef was constructed as its own market category by framing it as affirming moral values and in opposition to traditional beef. Lounsbury et al. (2003) demonstrate how frame changes supported the creation of a 
recycling industry. In the context of our study, frames of morality and ethics may play a crucial role in valuing Southern commodities.

Other studies have explored how practical operations around products have contributed to their value. Heuts and Mol (2013), for instance, draw attention to the different values of tomatoes depending on the practices surrounding them, whether cooking, eating, selling, or growing. Work in institutional theory offers similar insights. For example, in Rao et al.'s (2003) study of the proliferation of nouvelle cuisine in French cooking, the way the food was prepared and the menus organized and produced invoked certain values and helped define the concept of nouvelle cuisine. In a study of commercial activities in human cadavers, Anteby (2010) shows that specific trading practices surrounding goods can contribute to their morality. Thus, we propose that the way commodities are traded, sold, and presented may have the potential to infuse them with moral values.

Most previous studies have investigated the various valuation practices separately. In this study, we explore the range of valuation activities in which value architects engage over three decades to illuminate how a new value conceptualization of products is formed. By drawing on a concrete empirical application, the institutionalization of fair trade in Switzerland, our study sheds light on the role of values and valuation practices as important drivers of institutionalization processes. From an institutional analytical point of view, however, it is critical to also pay attention to whether the revalued products are judged as appropriate by the broader audience and whether the value architects can credibly imbue them with superior moral qualities. Only then will moral products develop into enduring and reproducible elements of the dominant social order (in our study the mainstream mass market) that no longer require justification; the new product category will be deemed 'valuable and worthy of support' (Suchman, 1995, p. 581).

\section{RESEARCH SETTING AND METHOD}

Our empirical setting is the birth and institutionalization of fair trade in Switzerland from 1970 to 1997. Fair trade is one of the earliest examples of products that explicitly evoke moral values and for which consumers are willing to pay a premium price. It is an official label that encompasses the trade of (food and non-food) products as a means of supporting small-scale farmers and producers in developing countries (Raynolds and Bennett, 2015). Fair trade has frequently been celebrated as an example of social innovation and is widely accepted in the mainstream market place. In fact, it is among the most wellknown labels that convey social value (Gourevitch, 2011). In 2013 alone, consumers spent 5.5 billion euros on certified fair trade products worldwide. ${ }^{4}$ While the impressive growth of fair trade, its organizational design, and its impact have been examined in great detail (e.g., Huybrechts, 2012; Jaffee, 2014), little research has explored its detailed origins and social meaning in contemporary Western societies.

We employed a qualitative research approach - the most appropriate given the limited work on how values and valuation underpin institutionalization processes (Edmondson and McManus, 2007). Switzerland offers an ideal research setting for our study. It is not only among the first countries in which fair trade products were locally invented, it also ranks highest in terms of fair trade consumption per capita. ${ }^{5}$ In 2014, retail sales reached 353206210 euros in this comparatively small country. ${ }^{6}$

Furthermore, Switzerland's distinct national cultural context, in which economic values and wealth play a 
dominant role, offers an opportune context in which to study how new valuation principles rooted in morality and social justice can find traction and legitimacy over time.

Notably, fair trade in Switzerland was institutionalized without incumbent endorsement. The country went through a very lively solidarity movement in the 1970s and 1980s, when numerous people and groups became actively involved in public campaigns to raise awareness about inequalities in NorthSouth relations and persistent economic and social issues in developing countries (Brunner, 1999; Kuhn, 2011; Strahm, 2008). These activities in the 1970s culminated in what is today known as fair trade. Correspondingly, the period of our study starts in 1970. It ends in 1997 when the Swiss fair trade boundaries became more porous due to internationalization and harmonization efforts and the creation of the Fairtrade Labelling Organizations International (FLO).

We chose to apply a process perspective and utilized an inductive case study design to gain deep insights into the historical valuation process (Yin, 2009). Process approaches focus on how and why phenomena emerge, develop, and unfold over time (Langley, 1999). To gain insights into the temporal valuation dynamics of fair trade, we built a longitudinal database drawing on extensive archival data (Ventresca and Mohr, 2002). We collected our data from several private and two public archives in Switzerland: the 'Sozialarchiv' (SozArch) in Zurich ${ }^{7}$ and the 'Dokumentationszentrum Alliance Sud' (Dokz) in Bern. ${ }^{8}$ The archival data are composed of annual reports, promotional material, newspaper clippings, press releases, flyers, and various internal documents of persons and organizations involved, such as protocols from workshops, board and office meetings, letters, and personal notes. We supplemented and triangulated the archival data with information from 28 semi-structured interviews with experts in the field. ${ }^{9}$ We also consulted books written by involved people and historians, contemporary publications, and information on web pages.

In our analysis, we mainly focused on the actors that engaged in valuation - the value architects - and their activities to establish and change the worth of previously unchallenged Southern commodities. As our overt focus was on how moral values were fabricated into products, we were less interested in scrutinizing Swiss consumers and their typical consumption behavior. We did, however, pay attention to the overall level of acceptance among the broader Swiss audience, including consumer reactions, the media, and the Swiss state. Similarly, we focused less on wider macro-level changes in the environment, such as major political and macro-economic shifts. Rather, we gave primacy to valuation activities 'on the ground'. To elaborate on our process perspective, we worked on a detailed narrative. We present a shorter version of our detailed historical narrative below.

\section{VALUING AND INSTITUTIONALIZING FAIR TRADE PRODUCTS IN SWITZERLAND}

Engaging with our data, we detected an interesting periodization. We identified three stages in the institutionalization of fair trade, each characterized by distinct valuation activities and value principles: an invention phase during which fairly traded products were utilized as campaign themes to raise awareness (1970-77); a niche phase during which fair trade became more codified and was promoted as an alternative to mainstream economic practice (1977-92); and a mainstream phase (1992-97) characterized 
by the creation of a standardization organization and the transition of fair trade products into the mass market.

\section{Phase 1: Invention (1970-77)}

What is today known as fair trade originated in the 1970s through a range of consumer campaigns. The campaigns aimed to raise awareness among the Swiss public regarding poverty, exploitation, and income inequalities in the Third World. Those problems were caused, according to the social movement activists, by conventional international trade. A heterogeneous mix of organizations and people engaged in these consumer campaigns and used simple Southern commodities such as coffee and bananas to attract attention, exemplify their grievances, and provide 'food for thought' to Swiss citizens. Among the activists were members of civic society organizations, well-established Swiss humanitarian aid organizations, church and women's groups as well as student activists. Most of the people involved were closely connected to a Christian church parish. The younger activists and student organizations were also politically motivated and generally supported anti-capitalism, pro-communism, and decolonization. ${ }^{10}$ The movement sought to sensitize the Swiss public to issues in the Third World and thereby 'invented' fairly traded products. The products played a key role during the social movement; most activities revolved around products that became increasingly associated with the movement's moral values, particularly social justice and solidarity.

Switzerland has a long-standing tradition of development aid and charity. Since the post-war period, the principle of solidarity has developed as a core characteristic of Swiss foreign policy, complementing the country's neutrality (Kuhn, 2011). The movement that mobilized in the 1970s criticized Switzerland's 'neutral solidarity', given its financial entanglements and trade relations with the Third World. Another background condition for this social mobilization was the upsurge of a new paradigm in development theory - dependency theory - that emphasized the negative aspects of international investment and explained poverty and underdevelopment in the Third World as consequences of structural dependencies on industrialized countries.

While some activists utilized 'conventionally' traded products in their campaigns, others sought to be more authentic and engaged in direct trade or, rather, the sporadic and unprofessional sourcing of Southern commodities from producer cooperatives in the Third World. Most campaigns were framed as 'trade not aid' campaigns, drawing on the slogan developed by the United Nations Conference on Trade and Development (UNCTAD) in 1968 to promote equitable trade relations with the South. By employing the 'trade not aid' frame, the activists aimed to upset Swiss consent on charity and development aid and to address trade relations and development policy.

In the 1970s, market access, product sales, and a fair income for Southern producers were not the goals of the fair trade movement. The products were used as campaign themes and attention-seeking devices to educate the public and problematize the lack of awareness of the Third World. For instance, as stated in one of the information brochures for a coffee campaign in 1975:

Purpose and meaning of the coffee campaign UJAMAA is awareness-raising. The sale. . of coffee alone does not help Tanzania and the rest of the Third World. The necessary changes in the world trade system demand major changes. For this, a new awareness is needed. (Campaign brochure, 1975, SozArch Ar 430.27.1) 
The activists sold coffee from Tanzania, jute bags from Bangladesh, and bananas from South America during street campaigns, in front of churches, during concerts and film showings, and at street theatres, street booths, farmers' markets, and lively city squares. Alongside the products, all activists distributed information brochures and flyers that stated their goals and grievances. They spent time and effort designing brochures, posters, flyers, and labels that they glued to the products, as well as other types of campaign material that were handed to the 'customers' when 'selling' the products. The campaigners also developed dossiers of up to 30 pages used to train activist-salespeople in which they discussed their 'sales' arguments and values in a comprehensive way. Another common activity was to write press articles stating the goals of the campaigns. In doing this, the activists extensively justified and explained their values and practices. They also explicitly drew attention to the origin of the products, the producers who generated them, and the conditions of production and trade - valuing practices that were of great importance to the movement, as they represented and rendered tangible both solidarity and social justice.

During this invention phase, the products were utilized as symbolic carriers (Scott, 1995) to convey to the public both information and the social values that were driving the movement. Although neither the trading nor the selling of the products was the goal in itself, all activists extensively explained why they would not just give the products away but instead were asking a price for them. The activists specifically stated that the selling and pricing of the products were symbolic activities. The campaign themes and campaign statements reflect this symbolic nature, using themes such as 'for example bananas' or 'e.g., coffee Ujamaa'. ${ }^{11}$ The sale of jute bags was purposefully meant to be a symbolic activity: 'The campaign "Jute not Plastic" is not about selling as many jute bags as possible, but to convey as much information as possible' (Campaign dossier, 1977, SozArch Ar 430.28.1). Similarly, one of the brochures for a coffee campaign says: 'e.g., coffee, our theme, seeks to illustrate with the help of coffee the inequality and exploitation in the international trade system. . . It is all about information and not the sales of coffee' (Campaign brochure, 1975, SozArch Ar 430.27.1).

The activists worked differently on issues of pricing, but pricing was specifically used as a value-based practice. For example, in campaigns involving the sale of bananas, conventional bananas were sold with an extra charge of 15 centimes to express solidarity. In campaigns focused on coffee, the price was set lower than the conventional market price to demonstrate that social justice does not have to cost more. ${ }^{12}$

Hence, in the process of campaigning, the activists started to introduce moral values. They began to link these values to products and expressed them through various product-related activities. For instance, a coffee campaign in 1973 advocated 'Coffee solidarity'. Another campaign in 1975 used the slogan 'Help people to help themselves: Solidarity coffee Ujamaa'. The solidarity value frame was one of the value frames that sought to make the products personally relevant to the audience and to evoke a connection between people in the South and Swiss consumers. Environmental values were also introduced and associated with the products. For example, the activists printed jute bags with the slogan 'Jute not Plastic' and valorized the products as an environmentally friendly alternative to plastic bags. The movement's social values were also extensively highlighted in the informational brochures and other devices that were distributed together with the products. 
However, the valuation activities of the activists were widely contested and assessed as inappropriate among the broader audience. Several rounds of accusations and letters to the editor in various Swiss newspapers described the activists' practices as 'abusing church money' or 'false statements'. Some of these instances even ended up as court cases. ${ }^{13}$ Letters between the social activists and one of the major Swiss retail chains showed that the direct trade and sale of Southern commodities was considered inappropriate for mass marketers as these retailers 'did not work like charity organizations' (Brunner, 1999). Furthermore, Swiss state authorities frequently surveyed some of the most salient activists (Strahm, 2008). Thus, in the 1970s, various external constituents, such as potential consumers, retail stores, and the Swiss state perceived the sales of fairly traded 'solidarity' products as highly suspicious.

While (still) externally contested, within the movement the practice of selling and trading consumer goods from developing regions, connected to ethical principles such as social justice and solidarity, increasingly appealed to like-minded groups and organizations. The movement gained more and more momentum and the campaigns grew in size and mobilization. For example, one of the first campaigns in 1973 involved the import and sale of one ton of instant coffee from Tanzania, while a later campaign in 1975 sold eight tons of coffee throughout Switzerland. ${ }^{14}$ Encouraged by this success, various movement groups and activists became interested in a more permanent form of campaigning. People started grouping together and founding world shops - unprofessional small shops operated on a voluntary basis with irregular opening hours - to sell Third World products. ${ }^{15}$ To handle larger campaigns, the main initiators and advocates behind the consumer campaigns approached several Swiss civil society organizations to gather the funding needed to start a formal importing organization that would address the practical operations surrounding fairly traded goods, such as the trade, shipping, and storage of the products, as well as their distribution throughout Switzerland.

The importing organization OS3 was formally registered in 1977. During the founding phase, the founding team, consisting of movement activists and representatives of some of the largest Swiss civil society organizations, elaborated on the general organizational principles. These principles formalized criteria regarding the type of products that would be selected, from whom and where they would be purchased, and how the products would be priced and marketed. With this elaboration, the moral value principles that had earlier been introduced and disseminated during the consumer campaigns became more codified and translated into more permanent sales and trading activities.

\section{Phase 2: Niche (1977-92)}

The importing organization OS3 was set up as a cooperative headquartered in Berne. This is not very surprising, as activists often turn to cooperatives in their effort to establish alternative economic orders and to maneuver outside of established institutions (Schneiberg et al., 2008). As such, 'pivoting towards capitalist business behavior' was explicitly degraded and prohibited according to the OS3 statutes. While the valuation activities that took place during this phase were initially still connected to the oppositional, change-oriented movement ideology, they were increasingly oriented towards creating a market for fairly traded products. With this reorientation, the focus on symbolic sales lessened, and Southern producers and their needs moved more and more toward center stage. The OS3 value architects (a mix of previous movement activists, newly mobilized followers, and representatives of well-established Swiss 
humanitarian aid organizations that helped finance OS3) engaged in a range of activities in which the conceptualization of the products increasingly shifted towards integrating social endeavors with a market orientation.

At the outset, OS3 was intended to organize larger and more permanent consumer campaigns for fairly traded products. Adopting a new and more stable organizational design, OS3 now permanently imported Southern commodities, which were then mainly sold through world shops - ethical sales outlets run by volunteers and fair trade activists throughout Switzerland. The operational activities were built around four general domains: product selection, pricing, informational work, and sales. ${ }^{16}$ Product selection was based on the goal of helping marginalized producers in the South and guided by values including the promotion of employment, self-reliance, environment, culture, solidarity, and socially acceptable working conditions. Establishing long-term partnerships with Southern producers became a central objective. In press statements, speeches, and mission statements, the OS3 value architects always made sure to connect the products to the values they perceived as important. They also tried to establish a connection between the producers and Swiss consumers. As such, OS3 perceived itself as a bridge between Southern producers and Northern consumers. As the president of OS3 explained in a public media statement in 1987:

The products are concrete, tangible signs of the work that is being done by men and women in the Third World, as well as signs of cultural values. . Through its products, OS3 connects the real situation of the producers in the Third World to the Swiss market. (Media statement, 1987, SozArch claro 4511)

Pricing was no longer used as a symbol and informational tool but instead centered on what the producers would consider an 'acceptable and just price'. Pricing became important in supporting the social values and goals OS3 promoted, particularly the creation of employment, better working and living conditions, and development opportunities for people in the Global South. OS3 offered the products at a solidarity price to guarantee producers a decent remuneration. For instance, as highlighted in OS3's mission statement from 1987: 'Better prices for the producers. Producers receive a cost-covering and an above-average remuneration for their products' (Mission statement, 1987, Dokz fair trade, claro).

Each product was sold with informational materials, often a brochure or flyer. The material devices elaborated on the origin of the products, drew attention to the producers and the socially beneficial production conditions, and highlighted the social values promoted by OS3, in particular social justice, the environment, and social development. Designing and distributing these materials was thus an important activity seeking to legitimate the alternative products, help Northern consumers to distinguish them from conventional products, and guide consumers' purchasing decisions towards the moral principles of worth proposed by OS3. This valuation work was taken very seriously. As stressed in a product brochure:

Our products must not merely be simple consumer goods but concrete signs coming from the producers, from other cultural regions. What makes the difference is the information about you, about the life of the people producing these goods, and their environment. (Information brochure for producers, 1984, SozArch claro 4511) 
OS3 also developed a logo that was attached to the products stressing 'work, justice, ecology, development'. ${ }^{17}$ OS3 sold both food (coffee, chocolate, honey, etc.) as well as non-food items (clothes, decorations, bags, etc.). Thus, the logo that OS3 developed allowed for a first categorization and identification of a number of fairly traded products subsumed under a set of moral values.

However, with the gradual shift from symbolic sales to creating an alternative niche market, selling Southern products became less and less a means of disseminating information and more and more an end in itself. Furthermore, while the sales of products rose during the early years (e.g., the turnover in 1977 was approximately $202000 \mathrm{CHF}$, and $3250000 \mathrm{CHF}$ in 1981), during the 1980s, OS3 witnessed stagnating sales. This downturn triggered internal debates about whether OS3 should open up to conventional sales channels. Debates about the pros and cons of appropriate distribution outlets began to dominate the activities of OS3, and OS3 constituents struggled in their position between ethical values and an increased commercial orientation. ${ }^{18}$ A world shop owner remarked in 1980: 'We would like to reach more people, but it cannot be allowed that commodities are just sold and no information work takes place anymore. What would distinguish us then from commercial shops?' (Press clipping, 1980, Berner Zeitung).

At the end of the 1980s, OS3 decided to expand towards a so-called semi-alternative field. ${ }^{19}$ With this, the organization sought to broaden the alternative market niche. Against this background, a Swiss newspaper featured 'The import organization between market and ideals' ${ }^{20}$ In fact, OS3, and the values and sales methods it promoted, were wedged in between civic ethics and the market, between movement- and market-oriented concepts. Changing the initial focus, which had been solely on social values, culminated in a volatile debate among the various members of OS3 about suitable sales outlets. Some members wanted to increase sales by opening up to mainstream commercial channels and downsizing the ideological agenda, while others strove to retain the goal of awareness-raising by promoting world shops as the only suitable distribution channel for fairly traded products and demonstrating a critical position towards commercialization efforts.

The number of world shops, which constituted the classical alternative point of sale, reached its peak some years after the creation of OS3. Thereafter, the numbers began to stagnate and even decreased. ${ }^{21}$ OS3 itself remained in an alternative niche, as it never actually cooperated with large conventional retailers, and the retailers showed little interest in a collaboration with OS3. However, despite these internal quarrels, the broader Swiss audience began to positively recognize the efforts around the ethically produced and traded products of OS3. The jute bags became a lifestyle product, enjoyed high demand, and were even exported to Germany and Austria. However, the typical world shop consumers were a relatively small circle of adopters.

This period of struggle and niche existence came to an end in 1991 when various Swiss relief organizations and members of OS3 decided to attempt bringing fairly traded products to the shelves of Swiss supermarkets. They advocated for this transition by arguing that more sales would make more of a difference for marginalized producers. They also highlighted the pressing need for more sales, as world market prices for coffee had dropped dramatically; hence, they combined their social orientation with a commercial mandate. A new, 'hybrid' person was enrolled to convince at least one of the two large Swiss supermarket chains, Coop or Migros, of the social and economic benefits of fair trade and to incorporate 
fair trade certified products into their offerings. ${ }^{22}$ The agent of the mission highlighted how he acted as a bridge between the two distinct worlds:

I come from these two worlds. Independent consulting office, MBA, man of business, but also six years in South America working for the DEZA [Swiss Agency for Development and Cooperation SDC]. With that I could function as a bridge. . .between producers and trade on the one hand and consumers on the other. (Interview, 2013)

The movement of fair trade products from an alternative niche into the conventional market place was further legitimated through the creation of a standardization organization and an official label. For this, an existing template of fair trade was adopted that had first been utilized in the Netherlands, the Max Havelaar initiative, which defined fair trade standards and offered a corresponding label. After both major Swiss supermarket chains - Coop and Migros - agreed to sell fairly traded coffee, the Max Havelaar Foundation Switzerland was launched in 1992 by several prestigious Swiss civil society organizations. With this move, civic virtues became integrated with economic values, and fair trade could move into the mainstream market place, notably without losing its moral credibility.

\section{Phase 3: Mainstream (1992-97)}

Although it was unthinkable 20 years ago that fair trade products would be sold in the mainstream market place, the value architects of fair trade products continued emphasizing the positive blend of social and economic values. The main value architect was now the standardization organization Max Havelaar Switzerland. Embedded in the institutional context of the 1990s - of rising private certification initiatives that addressed social and environmental issues (Bartley, 2007) - Max Havelaar emphasized its connection to the intensive solidarity efforts of the civil society pioneers while promoting the sales of fair trade through retail chains.

Particularly during its beginnings, the standardizer highlighted its close link to the Swiss fair trade pioneers to invoke credibility. In 1993, Max Havelaar presented the following goal:

Establishment of the Max Havelaar label as the only label for fairly traded Third World products, whereby we aim, in close collaboration with the other allies (relief organizations, OS3, association of Third World shops), at not diluting the concept of fair trade. (Annual Report Max Havelaar 1993)

Max Havelaar consistently referred to moral values such as solidarity, social justice, fair trading conditions, and the need for collectivity. Producers were not only guaranteed a fair remuneration but a worthy and sustainable livelihood. The products were presented as a win-win for everybody, for consumers as well as producers. Max Havelaar developed a product label that was attached to all products, stating 'a plus for all', thus synthesizing social and economic mandates and collapsing into a single slogan the various values that had previously been promoted. ${ }^{23}$

Max Havelaar focused its activities on marketing fairly traded products as broadly as possible and strengthening the popularity of certified fair trade products. The foundation searched for licensing partners that imported and sold products from developing countries according to their standards and made an effort to grow the product portfolio. ${ }^{24}$ In contrast to OS3, Max Havelaar neither imported nor traded Southern commodities itself. Rather, it defined fair trade rules, organized auditing mechanisms, and 
offered its label to commercial partners. Operational practices now concentrated on 'product development, producer monitoring, [and] market cultivation'. ${ }^{25}$ Conventional partners paid Max Havelaar a licensing fee to use the label. This was the foundation's main source of income. Over time, this licensing income has steadily increased, demonstrating the growing popularity and acceptance of fair trade among a broad audience (Figure 1).

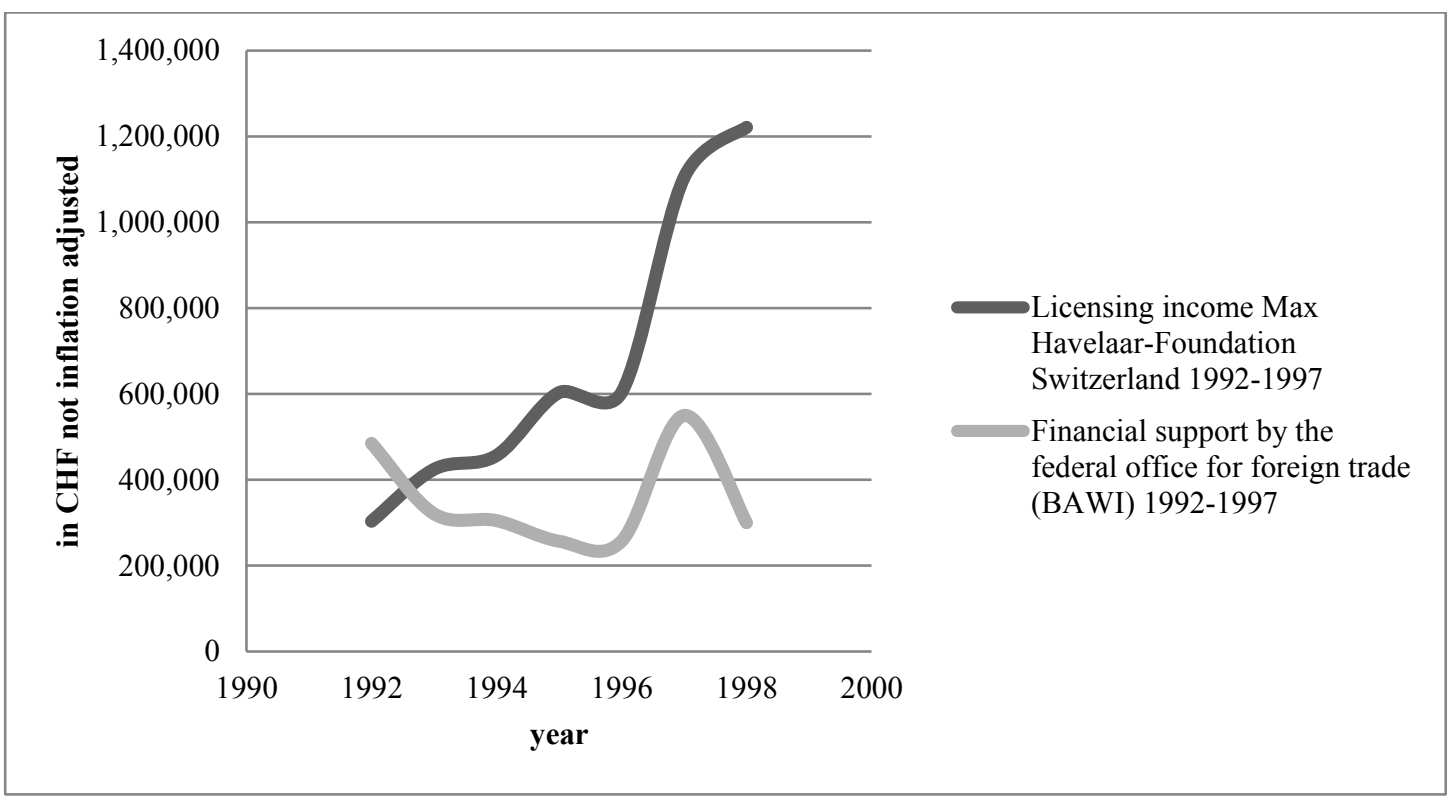

Figure 1. Licensing income of the Max Havelaar Foundation and financial support by the Federal Office for Foreign Trade (BAWI), 1992-99

With the creation of a standardizer and the cooperation of profit-oriented retailers, fair trade actors started to avail themselves of highly rationalized market devices. To value Southern commodities, they utilized a label to render fairly traded products distinguishable from conventional products and developed a set of formal standards that were characterized by high levels of abstraction and rationality (Loya and Boli, 1999). Formal standards gained great importance in the promotion and coordination of fair trade (Arnold and Hasse, 2015). Moreover, the pricing of the products was now based upon formalized and abstract practices. All prices were fixed on the basis of market prices (including differentials for quality) and a formula for calculating the fair trade price premium. This formula became standardized across all products and producers. ${ }^{26}$ In press clippings, it was then explained that the price premium was used to invest in education, technical production equipment, and other life-enhancing areas.

Under Max Havelaar, valuation activities became much more abstract and standardized compared to earlier periods, when activists and volunteers provided personal on-site explanation in the streets and distributed informational materials that would elaborate in detail on the moral values of the Southern commodities. In other words, moral values were now codified into a standard, a label, and a fair price; civic virtue became integrated into the mainstream, and compromise became crucial.

The launch of the fair trade standardization organization was funded by the Swiss Federal Office for Foreign Trade (BAWI) (see Figure 5.1), which previously had not supported any of the fair traders despite their efforts to apply for such funding. This already hints at the growing level of acceptance by 
external constituents. However, it was not only the government that now assessed fair trade products as desirable and worthy of support; there was also beneficial media coverage in Swiss newspapers. ${ }^{27}$ Additionally, a growing number of Swiss consumers accepted and bought the more expensive products. The market share of fair trade coffee rapidly reached 5 percent just the year after fair trade coffee became available on the supermarket shelves. ${ }^{28}$ Finally, the supermarkets were also pleased with the launch of fair trade coffee as it contributed to reputational gains and allowed them to explore new business opportunities. An informant from a supermarket chain enthusiastically explained: 'I explain what we do with the coffee. And it was the first time - at least I perceive it like this - that people positively reported on Coop in the Kassensturz [critical and popular consumer magazine on Swiss television]' (interview, 2013). The launch of fair trade coffee was also presented in the supermarket's promotional magazine. In doing this, the in-house editor emphasized that it is worth paying more for fair trade, thus evoking the harmony of social and economic value. A sophisticated female consumer of fair trade coffee was introduced in the following way:

For Anita Sommer, the coziness of a good cup of coffee is a piece of quality of life. She prefers coffee that is not too strong, but also not too mild. However, very aromatic. Like the Coop Café Solidaridad, for which she is even willing to pay more. (Press clipping, 1992, Coop-Zeitung)

Under Max Havelaar, fairly traded products became institutionalized. A wide range of products was now sold under a single label that was widely recognized, commonly understood, and increasingly taken for granted. In 1993, only one year after its launch, a first survey examined the level of awareness of Max Havelaar products and revealed that around one-third of Swiss citizens recognized the fair trade coffee. ${ }^{29}$ Since then, its degree of familiarity, as well as its revenues, have consistently increased (as depicted in Figure 5.1). ${ }^{30}$ This rapid acceptance of fair trade products and their success in Swiss retail is impressive, as the label and the price were the only devices that made the products' moral value visible to consumers. This suggests that the moral and economic worth of the products was mainly created during the previous stages, anchored in historical valuation practices.

However, while Max Havelaar and mainstream certified fair trade products became increasingly popular, the alternative movement was losing its appeal, a trade-off that many value-driven market categories experience during growth and diffusion (Mulgan, 2006).

\section{DISCUSSION OF KEY RESULTS}

Our case study depicts a process during which the conceptualization of the products (their moral and economic worth) changed and during which fairly traded products became institutionalized as a wellunderstood moral product category marked by a single label and standardized price. We suggest that this institutionalization of fair trade is the outcome of a historical valuation process. During the course of this process, the value architects of the fair trade movement provoked new valuation criteria and changed the social and economic worth of the products. They did so by relying on various market devices (brochures, press clippings, flyers, standards, labels), price setting, and framing as well as practical operations that would render visible the products' moral qualities and that would be in line with and guided by their social values. The findings of our case study suggest that shifts in valuation over time, and in particular 
the more recent blending of social and economic values, enabled fair trade to grow out of its niche and settle into the domain of the mainstream market place as a highly credible product category imbued with moral values.

Initially, the products were utilized as 'symbols' of morality marked by a symbolic price set by movement activists to establish ties of solidarity between Southern producers and Northern consumers and to protest against conventional international trade and the dominant political and economic order. Then, the pioneering value architects codified their moral principles into permanent selling and trading practices and framed fair trade as an 'alternative' to conventional economic practice. Fair trade products were sold at a solidarity price that was set in accordance with the individual producers and what the producers perceived as fair. During that time, the various social values became bundled and associated with a portfolio of products (coffee, tea, and clothes were all sold by stressing work, justice, ecology, and development), albeit this valuation was still justified in detail. Both the invention and niche phases were marked by high levels of contestation: during invention, external constituents challenged the new moral valuation principles, and during the niche phase, internal constituents - the movement activists and niche supporters themselves - struggled in their position between ethical and commercial values.

In the 1990s, fair trade moved into the conventional market place as 'a plus for all' sold at a fair price - moral and economic values became tightly integrated. With this shift in valuation, civic virtues became integrated with economic values, and fair trade could enter the mainstream market place without losing its moral legitimacy. The value architects now concentrated on guaranteeing the moral value of imported coffee and other fair trade products through the abstract and rational practices of standardizing and labeling. A standardization organization and label were formed that 'certified' the moral qualities of the products and that no longer explicitly elaborated the moral value principles. Additionally, prices became standardized across products and producers. This rationalization of fair trade enabled its fast diffusion and reproduction in the mainstream, where the fair trade product category became more and more taken for granted. A growing number of consumers decided that it was worth paying a higher price for fair trade coffee. Simultaneously, the media and the government positively valued moral products through favorable reporting and substantial start-up funding. Hence, in the aftermath of the two earlier phases of activism and niche existence, moral products came to be understood as highly valued by a broad audience. We summarize this valuation and institutionalization process of fair trade in Figure 2. 


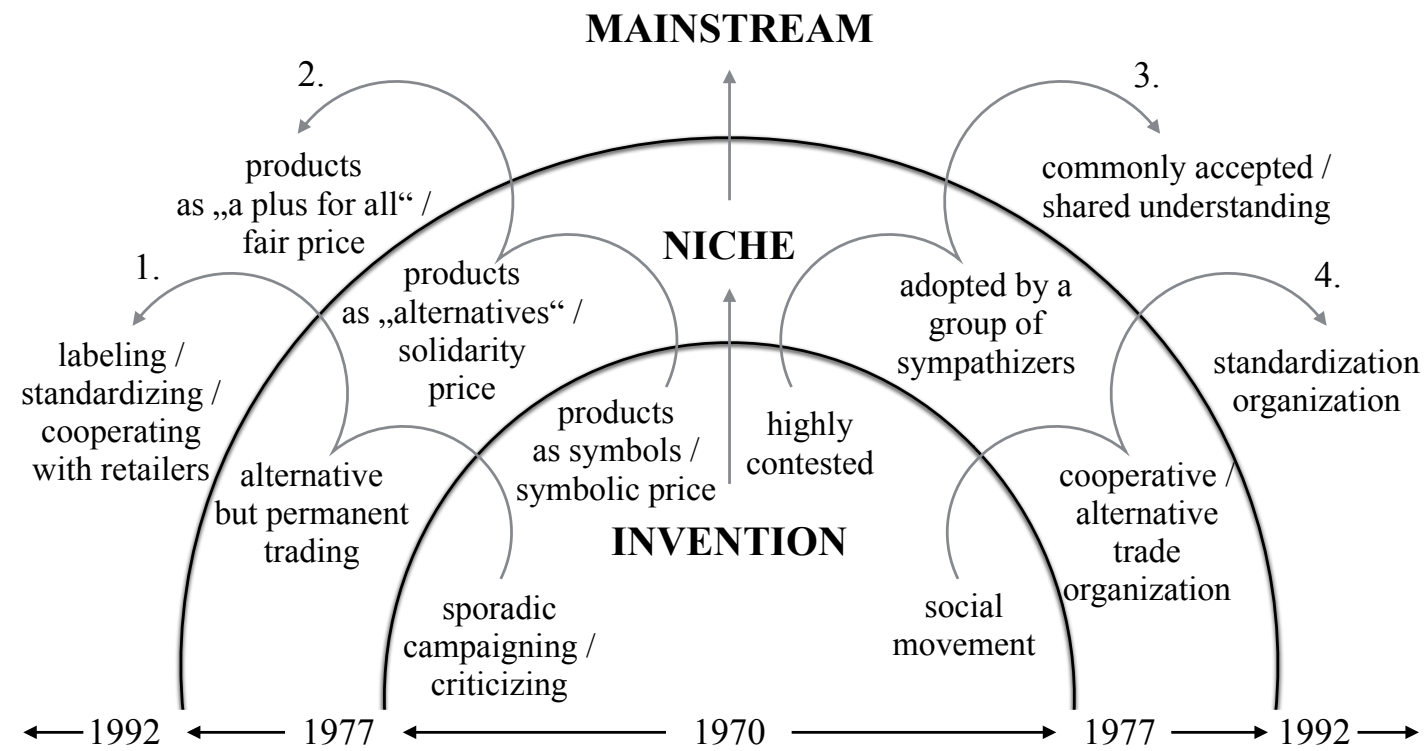

1. Valuation practices of value architects

2. Frame and pricing of products

3. Level of acceptance among the audience

4. Organizational form of value architects

Figure 2. Valuing and institutionalizing fair trade products in Switzerland, 1970-97

Bridging institutional analysis with recent developments in the literature on valuation offers valuable insights for the study of values in institutional theory. Particularly, our study contributes to elucidating the important role of values and valuation dynamics in processes of institutionalization and socio-economic shifts.

First, our longitudinal approach reveals that the institutionalization of fair trade as a moral product category in the mainstream mass market was not intended at the outset but was underpinned by a historical valuation process and driven by shifts in valuation. Scott (1987) characterized institutionalization as a process of creating social order over time and emphasized the necessity of employing an historical approach, as institutions always have a history. 'It is impossible to understand an institution adequately without an understanding of the historical process in which it was produced' (Berger and Luckmann, 1967, pp. 54-5, cited in Scott 1987, p. 495). Thus, our study provides deep insights into an historical institutionalization process. By cross-fertilizing literatures on institutional theory and economic sociology of valuation, this study sheds light on how valuation is created and shaped and provides insights into socio-economic transformations fueled by valuation dynamics. The main valuation activities used to provoke new values and associate products with superior moral qualities included the use of market devices and frames as well as operations surrounding the products. While previous work has dealt with each of those practices separately, our study reveals that the various practices were used in tandem and together shaped the worth and categorization of the products. Hence, we emphasize that the institutionalization of moral products is a historical and collective process whose outcome is anything but predictable and certain. We find that introducing new valuation principles does 
not come without costs. During the course of this process, changing the conceptualization of the products created tensions both among the external audience and internally among the value architects. However, the origins of what is today a widely appreciated product category are no longer connected to those sharp contestations. Applying an historical lens allows us to trace the institutionalization process back to its origins and reveal these important transformations.

Second, we introduce the concept of 'value architects' and show how the value architects of fair trade contributed to establishing a market for fair trade products by engaging in a range of practices that highlighted moral qualities and attributed them to the products. Identifying the value architects who have left their moral imprint on the products reveals that they have all been rooted in civil society (the social movement, the alternative importing organization, and the standardization organization). Interestingly, in our Western research setting, the producers themselves did none of the valuation work, and little took place in the mainstream market place. This is an interesting finding for the literature on valuation, which primarily focuses on economic valuation in market settings and the role of market actors such as producers, consumers, and market intermediaries. Our findings show that the valuing of the products mainly took place in the sphere of civil society, during the two decades before the products were launched in the mainstream. Such a finding speaks to Zelizer's work showing that social movement organizations played an important role in valuing life insurance (Zelizer, 1979). However, Zelizer mainly sheds light on the role of discourse. Our study builds on these insights and also pays attention to other important valuation practices that value architects can employ.

More generally, we assert that values are not created automatically, nor do they become automatically attached to things and ideas. We conceive of value architects as individuals or collectives, informal or formal groups that contribute to the construction of value by actively engaging in valuation activities. They provoke, infuse, and establish new valuation principles through their own activities. Their valuation practices are also shaped by societal influences and can evolve over time. Taken together, this can result in a new value system that may fuel the creation of new institutions (such as markets) or the transformation of existing ones. In the context of markets, value architects can be individual or collective actors inside and outside of established markets, such as producers, consumers, and intermediaries, as well as social movement activists, the media, and religious groups.

We perceive value architects and the related institutionalization process as markedly different from the institutional entrepreneur, a concept on which existing work in institutional theory has increasingly focused. Institutional entrepreneurs are defined as astute change agents that have an interest in particular institutional arrangements and mobilize resources to intentionally and purposefully bring about change (Battilana et al., 2009; DiMaggio, 1988; Hardy and Maguire, 2008). The concept of the institutional entrepreneur is one that stresses agency, intent, interest, and resources. In contrast, by putting forth the concept of value architects, we emphasize the roles of values, practices, and activities in constructing or shaping institutions. In our study, we demonstrate that the institutionalization and mainstreaming of fair trade were not explicitly intended at the outset. Rather, the collective and valuedriven activities of the value architects resulted in an outcome that turned out to be quite different from the initial objectives pursued.

Regarding the literature on valuation, the bulk of research has focused on market actors and valuation practices in market settings. In contrast, we portray value architects as individual or collective 
actors that operate inside and outside of established markets. In our study, actors in civil society turned out to be crucial value architects that constantly worked on the valuation of imported consumer goods from developing countries. Social movement and civil society actors continued instilling moral values by referring to social justice, solidarity, care for the environment, and societal development. Our research thus provides further evidence that value architects other than market actors might shape valuation and institutionalization processes (Dubuisson-Quellier, 2013; Zelizer, 2011).

Third, our study extends insights into the creation of moral markets (McInerney, 2014; Stehr, 2008). We suggest that, in particular, the blending of social and economic mandates may trigger important socio-economic transformations, including the creation of moral product categories, the orientation of social movements and social enterprises towards market-oriented activities and organizational forms, and collaborations among not-for-profit and for-profit organizations. As such, we contend that social and economic value can conflate and we place emphasis on valuation dynamics (Boltanski and Thévenot, 2006). Bringing together social and economic mandates in a new blend can catalyze new market activities and organizational transformations. While we see these transformations at the product, social, and organizational levels as related phenomena, in this chapter we have mainly focused our attention on the product level and the construction of the products' moral worth. More research is needed to further unpack the social and organizational transformations that may unfold in tandem in the creation of moral markets.

Similarly, we have paid less attention to the wider normative and cognitive changes that may have facilitated the revaluation of the products or triggered changes in valuation practices. Naturally, the observed trend that we depict is not particular to fair trade. The transition from an oppositional, alternative niche, and movement ideology attracting like-minded followers to new mainstream economic fields characterized by synthesizing social and economic mandates, are observable in numerous other examples such as microfinancing, ethical investing, community banking, organic food, and green energy. Certainly, these shifts have occurred against the backdrop of the wider contextual dynamics that we briefly discuss. First, an important impetus of change may have been reactions to a neoliberal market economy and the expansion of globally operating multinational firms since the late 1970s. In this context, social movements and corporate watchdog organizations grew, and corporate accountability and ethical responsibility considerations intensified, producing shifts in cultural norms towards human rights and equality and fostering new forms of governance and the rise of private certification initiatives that particularly addressed social and environmental issues in the business world (e.g., Bartley, 2003, 2007; Shorette, 2014). Second, the last three decades have witnessed an important transformation toward what we call a 'hybrid system': the once largely impermeable boundaries between civil society and the marketplace have become increasingly porous (e.g., De Bakker et al., 2013). Instances of this hybrid system are manifold: an increasing intermingling of the not-for-profit with the for-profit world, a tendency of social movements to collaborate with actors in the marketplace instead of choosing them as targets, and the rise of novel organizational forms like social enterprises that combine both social and economic mandates. These wider shifts resonate with the changes in valuation practices and the increased integration of social and economic values that we observe in fair trade. More research is needed on the institutional conditions that may give rise to the construction of new valuation principles and on the consequences of such value shifts. 


\section{CONCLUSION}

This study was motivated by a desire to more fully understand the creation and institutionalization of moral markets. Specifically, we explored how moral values become fabricated into products. More generally, our study contributes to a better understanding of the role of values and valuation dynamics as important drivers of institutionalization processes. How something becomes institutionalized is a key question in institutional theory. Although values are 'the guts of institutions' (Stinchcombe, 1997, p. 17) and central to what makes institutions influential and meaningful, institutional analyses often approach this question by drawing on relational or cultural accounts. By focusing on values and valuation practices, we join recent efforts that seek to revitalize the attention to values in institutional theory (Kraatz and Flores, 2015).

We entered this exciting conversation by borrowing tools from the literature on valuation in economic sociology. We did so to offer a theoretical framework through which the study of values can be introduced into institutional analysis. This provided an opportunity to grapple with institutionalization processes in new ways. Inspired by the literature on valuation, we investigated in detail how value is socially constructed, how new valuation principles are being created, and by whom. In the context of our study, we shed light on how the infusion of values underpinned the institutionalization of a new product category and how shifts in valuation principles at the intersection of business and society could contribute to socio-economic transformations, such as the reconfiguration and creation of moral markets.

Prior studies in institutional theory have heavily emphasized the role of discourse as a carrier of meaning that can make new ideas understandable and appealing. Drawing on the valuation literature, we showed that material devices and operational activities were critical in invoking, legitimating, and embodying values and meaning. In this sense, our study extends the work on discourse and contributes to more recent attempts in institutional theory interested in a practice and materiality turn. Furthermore, institutional theory has tended to devote less attention to exploring the micro sources of macro outcomes. This study contributes to calls for such micro-level investigations by illuminating the important role of 'on the ground' valuation practices in producing a product market category imbued with moral values.

Further research is needed that extends the insights and findings of our study. For example, future research should be extended to other types of market contexts and product categories and should investigate the practices of value architects concerned with aesthetic values (as in art) or cultural values (as in the slow food movement). Another avenue for future research is to explore the role of values and valuation dynamics in new product development and the commercialization of new technologies, for example in the context of new environmental technologies such as electric cars or smart grids. We hope that our study can provide inspiration for more work on values and institutions, and for studying processes of change at the intersection of business and society.

\section{REFERENCES}

Antal, A.B., M. Hutter and D. Stark (eds) (2015), Moments of Valuation: Exploring Sites of Dissonance, Oxford: Oxford University Press.

Anteby, M. (2010), 'Markets, morals, and practices of trade: Jurisdictional disputes in the U.S. commerce in cadavers', Administrative Science Quarterly, 55(4), 606-38. 
Arnold, N. and R. Hasse (2015), 'Escalation of governance: Effects of voluntary standardization on organizations, markets and standards in Swiss fair trade', Sociological Research Online, 20(3), accessed 21 March 2017 at http://econpapers.repec.org/article/srosrosro/2015-3-3.htm.

Aspers, P. and J. Beckert (2011), 'Value in markets', in J. Beckert and P. Aspers (eds), The Worth of Goods: Valuation and Pricing in the Economy, Oxford: Oxford University Press, pp. 3-40.

Bartley, T. (2003), 'Certifying forests and factories: States, social movements, and the rise of private regulation in the apparel and forest products fields', Politics and Society, 31(3), 433-64.

Bartley, T. (2007), 'Institutional emergence in an era of globalization: The rise of transnational private regulation of labor and environmental conditions', American Journal of Sociology, 113(2), 297-351.

Battilana, J., B. Leca and E. Boxenbaum (2009), 'How actors change institutions: Towards a theory of institutional entrepreneurship', The Academy of Management Annals, 3(1), 65-107.

Beckert, J. and P. Aspers (eds) (2011), The Worth of Goods: Valuation and Pricing in the Economy, Oxford: Oxford University Press.

Benford, R.D. and D.A. Snow (2000), 'Framing processes and social movements: An overview and assessment', Annual Review of Sociology, 26(1), 611-39.

Berger, P.L. and T. Luckmann (1967), The Social Construction of Reality: A Treatise in the Sociology of Knowledge, New York: Anchor.

Boltanski, L. and L. Thévenot (2006), On Justification: Economies of Worth, Princeton, NJ: Princeton University Press.

Brunner, U. (1999), Bananenfrauen [Banana Women], Frauenfeld: Huber + Company AG.

Callon, M., Y. Millo and F. Muniesa (eds) (2007), Market Devices, Malden, MA: Blackwell Publishing.

De Bakker, F., F. den Hond, B. King and K. Weber (2013), 'Social movements, civil society and corporations:

Taking stock and looking ahead', Organization Studies, 34(5-6), 573-93.

Dewey, J. (1939), Theory of Valuation, Chicago, IL: University of Chicago Press.

DiMaggio, P.J. (1988), 'Interest and agency in institutional theory', in L.G. Zucker (ed.), Institutional Patterns and Organizations: Culture and Environment, Cambridge, MA: Ballinger, pp. 3-21.

Djelic, M.-L. and A. Ainamo (1999), 'The coevolution of new organizational forms in the fashion industry: A historical and comparative study of France, Italy, and the United States', Organization Science, 10(5), 622-37.

Dubuisson-Quellier, S. (2013), 'A market mediation strategy: How social movements seek to change firms' practices by promoting new principles of product valuation', Organization Studies, 34(5-6), 683-703.

Edmondson, A.C. and S.E. McManus (2007), 'Methodological fit in management field research', Academy of Management Review, 32(4), 1246-64.

Espeland, W.N. and M.L. Stevens (1998), 'Commensuration as a social process', Annual Review of Sociology, 24(1), 313-43.

Fourcade, M. (2011), 'Cents and sensibility: Economic valuation and the nature of "nature", American Journal of Sociology, 116(6), 1721-77.

Gehman, J., L.K. Treviño and R. Garud (2013), 'Values work: A process study of the emergence and performance of organizational values practices', Academy of Management Journal, 56(1), 84-112.

Glynn, M.A. and C. Navis (2013), 'Categories, identities, and cultural classification: Moving beyond a model of categorical constraint', Journal of Management Studies, 50(6), 1124-37.

Gourevitch, P. (2011), 'The value of ethics: Monitoring normative compliance in ethical consumption markets', in J.

Beckert and P. Aspers (eds), The Worth of Goods: Valuation and Pricing in the Economy, Oxford: Oxford University Press, pp. 86-105.

Hardy, C. and S. Maguire (2008), 'Institutional entrepreneurship', in R. Greenwood, C. Oliver, R. Suddaby and K. Sahlin-Andersson (eds), The SAGE Handbook of Organizational Institutionalism, Thousand Oaks, CA: SAGE, pp. 198-217. 
Heuts, F. and A. Mol (2013), 'What is a good tomato? A case of valuing in practice', Valuation Studies, 1(2), 12546.

Huybrechts, B. (2012), Fair Trade Organizations and Social Enterprise: Social Innovation through Hybrid Organization Models, London and New York: Routledge.

Jaffee, D. (2014), Brewing Justice: Fair Trade Coffee, Sustainability, and Survival, 2nd edition, Berkeley, CA: University of California Press.

Khaire, M. and R.D. Wadhwani (2010), 'Changing landscapes: The construction of meaning and value in a new market category - modern Indian art', Academy of Management Journal, 53(6), 1281-304.

Kraatz, M.S. and R. Flores (2015), 'Reinfusing values', in M. Lounsbury (ed.), Research in the Sociology of Organizations, Vol. 44: Institutions and Ideals: Philip Selznick's Legacy for Organizational Studies, Bingley, UK: Emerald, pp. 353-81.

Kuhn, K. (2011), Entwicklungspolitische Solidarität: Die Dritte-Welt-Bewegung in der Schweiz zwischen Kritik und Politik (1975-1992) [Development Aid Policy and Solidarity: The Third World Movement in Switzerland Between Criticism and Politics (1975-1992], Zürich: Chronos Verlag.

Lamont, M. (2012), 'Toward a comparative sociology of valuation and evaluation', Annual Review of Sociology, 38(1), 201-21.

Langley, A. (1999). 'Strategies for theorizing from process data', Academy of Management Review, 24(4), 691-710. Lounsbury, M., M. Ventresca and P.M. Hirsch (2003), 'Social movements, field frames and industry emergence: A cultural-political perspective on US recycling', Socio-Economic Review, 1(1), 71-104.

Loya, T.A. and J. Boli (1999), 'Standardization in the world polity: Technical rationality over power', in J. Boli and G.M. Thomas (eds), Constructing World Culture: International Nongovernmental Organizations since 1875, Stanford, CA: Stanford University Press, pp. 169-97.

McInerney, P.-B. (2014), From Social Movement to Moral Market, Stanford, CA: Stanford University Press.

Mulgan, G. (2006), 'The process of social innovation', Innovations: Technology, Governance, Globalization, 1(2), $145-62$

Muniesa, F. (2011), 'A flank movement in the understanding of valuation', The Sociological Review, 59(Special Issue), 24-38.

Porac, J.F., J.B. Wade and T.G. Pollock (1999), 'Industry categories and the politics of the comparable firm in CEO compensation', Administrative Science Quarterly, 44(1), 112-44.

Rao, H., P. Monin and R. Durand (2003), 'Institutional change in Toque Ville: Nouvelle cuisine as an identity movement in French gastronomy', American Journal of Sociology, 108(4), 795-843.

Raynolds, L.T. and E.A. Bennett (eds) (2015), Handbook of Research on Fair Trade, Cheltenham, UK and Northampton, MA, USA: Edward Elgar Publishing.

Reinecke, J. and S. Ansari (2015), 'What is a "fair” price? Ethics as sensemaking', Organization Science, 26(3), 86788.

Rosa, J.A., J.F. Porac, J. Runser-Spanjol and M.S. Saxon (1999), 'Sociocognitive dynamics in a product market', Journal of Marketing, 63(4), 64-77.

Schneiberg, M., M. King and T. Smith (2008), 'Social movements and organizational form: Cooperative alternatives to corporations in the American insurance, dairy, and grain industries', American Sociological Review, 73(4), 63567.

Scott, W.R. (1987), 'The adolescence of institutional theory', Administrative Science Quarterly, 32(4), 493-511.

Scott, W.R. (1995), Institutions and Organizations, Thousand Oaks, CA: SAGE.

Selznick, P. (1957), Leadership in Administration: A Sociological Interpretation, New York: Harper \& Row.

Sheperd, D.A., H. Patzelt and R.A. Baron (2013), “"I care about nature, but. . .”: Disengaging values in assessing opportunities that cause harm', Academy of Management Journal, 56(5), 1251-73. 
Shorette, K. (2014), 'Nongovernmental regulation and construction of value in global markets: The rise of fair trade, 1961-2006', Sociological Perspectives, 57(4), 526-47.

Stark, D. (2009), The Sense of Dissonance: Accounts of Worth in Economic Life, Princeton, NJ: Princeton University Press.

Stehr, N. (2008), Moral Markets: How Knowledge and Affluence Change Consumers and Products, Boulder, CO: Paradigm Publishers.

Stinchcombe, A.L. (1997), 'On the virtues of the old institutionalism', Annual Review of Sociology, 23(1), 1-18.

Strahm, R. (2008), 'Der aktionserprobte Achtundsechziger im Team der EvB 1974-1978' [The action-proofed member of the sixty-eight generation in the team of the DoB (Declaration of Berne) 1974-1978], in A.-M.

Holenstein, R. Renschler and R. Strahm (eds), Entwicklung heisst Befreiung: Erinnerungen an die Pionierzeit der Erklärung von Bern (1968-1985), Zürich: Chronos Verlag, pp. 113-66.

Suchman, M.C. (1995), 'Managing legitimacy: Strategic and institutional approaches', Academy of Management Review, 20(3), 571-610.

Suddaby, R., K.D. Elsbach, R. Greenwood, J.W. Meyer and T.B. Zilber (2010), 'Organizations and their institutional environments - bringing meaning, values, and culture back in: Introduction to the special research forum', Academy of Management Journal, 53(6), 1234-40.

Vaccaro, A. and G. Palazzo (2015), 'Values against violence: Institutional change in societies dominated by organized crime', Academy of Management Journal, 58(4), 1075-101.

Ventresca, M.J. and J.W. Mohr (2002), 'Archival research methods', in J.A.C. Baum (ed.), Blackwell Companion to Organizations, Malden, MA: Blackwell Publishing, pp. 805-28.

Waarden, F.V. and R. van Dalen (2013), 'Halal and the moral construction of quality: How religious norms turn a mass product into a singularity', in J. Beckert and C. Musselin (eds), Constructing Quality: The Classification of Goods in the Economy, Oxford: Oxford University Press, pp. 197-222.

Weber, K., K.L. Heinze and M. DeSoucey (2008), 'Forage for thought: Mobilizing codes in the movement for grassfed meat and dairy products', Administrative Science Quarterly, 53(3), 529-67.

Yenkey, C. (2011), 'Selling value in Kenya's Nairobi stock exchange', in J. Beckert and P. Aspers (eds), The Worth of Goods: Valuation and Pricing in the Economy, Oxford: Oxford University Press, pp. 247-71.

Yin, R.K. (2009), Case Study Research: Design and Methods (4th edition), Thousand Oaks, CA: SAGE.

Zelizer, V.A. (1979), Morals and Markets, New York: Columbia University Press.

Zelizer, V.A. (1989), 'The social meaning of money: "Special monies”, American Journal of Sociology, 95(2), 34277.

Zelizer, V.A. (2011), Economic Lives: How Culture Shapes the Economy, Princeton, NJ: Princeton University Press. Zuckerman, E.W. (1999), 'The categorical imperative: Securities analysts and the illegitimacy discount', American Journal of Sociology, 104(5), 1398-

\footnotetext{
${ }^{1}$ To document the increasing proliferation of moral products, the Canadian Big Room Company tracks the growth of ethical product labels worldwide. Currently, there are 463 labels reported, accessed November 29, 2015 at http://www.ecolabelindex.com/.

${ }^{2}$ We define value architects as individuals, informal groups, and organizations that contribute to the construction of value by actively engaging in valuation activities. Value architects actively promote, infuse, and establish new valuation principles through their own activities. In the context of markets, value architects can be individual or collective actors inside and outside of established markets, such as producers, consumers, and intermediaries, as well as social movement activists, the media, and religious groups.

${ }^{3}$ The term 'value' as used in the valuation literature often has a monetary connotation. In this study, when we use the terms value and valuation, we do not explicitly mean economic value; rather, we refer to the blending of moral and economic principles of worth.

${ }^{4}$ Strong Producers, Strong Future, Annual Report 2013-14, Fairtrade International.
} 
${ }^{5}$ In 2014, Swiss consumers spent on average 57 CHF each on certified fair trade products (Changing Trade, Changing Lives, Annual Report 2015 Fairtrade Max Havelaar, Switzerland).

${ }^{6}$ Strong Producers, Strong Future, Annual Report 2013-14, Fairtrade International.

${ }^{7}$ Investigated folders include 'Erklärung von Bern' (EvB) (Sign. Ar 430), 'claro fair trade AG' (Sign. Ar claro), and ‘Arbeitsgruppe Dritte Welt Bern' (Sign. Ar 44).

${ }^{8}$ Investigated folders include 'Fairer Handel' and 'Rohstoffe'.

${ }^{9}$ Interview data are drawn from a research project supported by the Swiss National Science Foundation, grant no. 100017_134588.

${ }^{10}$ The 1960s saw an upsurge of social conflicts all over the world, manifested in the student movement of 1968, anti-war protests (particularly in reaction to the Vietnam War but also the Cold War), and the support of the decolonization efforts of previous African colonies. Several wars of independence took place in the 1960s, including in Angola (Angolan War of Independence, 1961 to 1974), Biafra (Nigerian-Biafran Civil War, 1967 to 1970), and Guinea (Guinea-Bissau War of Independence, 1963 to 1974).

${ }^{11}$ Promotional magazine 1973, Zum Beispiel Bananen, private property of an informant, and campaign dossier 1975 'z.B. Kaffee Ujamaa. Dossier zur Verkäuferschulung', SozArch Ar 430.27.1.

${ }^{12}$ Campaign dossier 1975: 'z.B. Kaffee Ujamaa. Dossier zur Verkäuferschulung', SozArch Ar 430.27.1.

${ }^{13}$ Internal document 31 July 1997: 'Schweizerisches Ost-Institut verbreitet grobe Unwahrheiten über die Kaffee-Aktion Ujamaa', SozArch 430.10.2, and press release on SHZ Report, 25 May 1979: 'Am Anfang war eine Jute-Idee. Erfolgreiche Verkaufsaktion Günstiger Abschluss - Zweckentfremdung eines grossen Teils der Aktionsgelder’, SozArch Ar 430.28.4.

${ }^{14}$ Campaign dossier 1975: 'z.B. Kaffee Ujamaa. Dossier zur Verkäuferschulung', SozArch Ar 430.27.1.

${ }^{15}$ The first world shop was founded in the city of Uster in 1974. It soon became a template for activists in other Swiss regions (Strahm, 2008).

${ }^{16}$ OS3 statutes, 22 June 1977: 'Grundsätze der Geschäftspolitik', SozArch claro 1010.2.

${ }^{17}$ Press folder 1987: 'Pressemappe OS3, Medientag vom 13.05.1987’, SozArch claro 4511.3.

${ }^{18}$ Magazine article in Mosquito, January 1987, 'Alternativhandel: Jein zum Kommerz’.

${ }^{19}$ Mission statement 1987 OS3, Dokz fair trade, claro.

${ }^{20}$ Press clipping Neue Zürcher Zeitung 14 May 1987, 'Dritteweltprodukte auf dem Weg zum bewussten Käufer. Die Importstelle OS3 zwischen Markt und Idealen'.

${ }^{21}$ Four hundred world shops were counted in 1983; since then, the number of world shops has decreased. Internal document 1983 : 'Ein entwicklungspolitisches Label - Chancen und Probleme', SozArch Ar 430.30.4.

${ }^{22}$ Internal document 1990: 'Sauberer Kaffee. Für eine Kaffeekampagne in der Schweiz', SozArch claro 7100.11.

${ }^{23}$ Speech of the first managing director of Max Havelaar Switzerland on the occasion of the foundation's 20th anniversary in 2012.

${ }^{24}$ Between 1992 and 1997, the following fair trade products were launched in Switzerland: coffee (1992), honey (1993), cocoa and sugar (1994), tea (1995), and bananas (1997). Annual Reports Max Havelaar Switzerland 1992-97.

${ }^{25}$ Published report 1996: Erfahrungen der Max Havelaar-Stiftung beim Vertrieb von Produkten aus Entwicklungsländern, available at http://sjep.revues.org/1346 (accessed 17 February 2015).

${ }^{26}$ Max Havelaar conditions for the purchase of coffee, 1991, private archive of an informant.

${ }^{27} \mathrm{We}$ found a positive media tone reporting on the launch of fair trade coffee in conventional retail stores in various Swiss newspapers. Press review Max Havelaar claro 1991-97, SozArch claro 7106.1.

${ }^{28}$ Annual Report Max Havelaar Switzerland 1993.

${ }^{29}$ Annual Report Max Havelaar Switzerland 1993.

${ }^{30}$ By 1994, the public awareness of the foundation had already increased up to 42 percent. Annual Report Max Havelaar

Switzerland 1994. 
